\title{
The Mechanical Atatürk: Cybernetics and State Violence in the Second Turkish Republic
}

\author{
Joakim Parslow (D) \\ Department of Culture Studies and Oriental Languages, University of Oslo, Oslo, Norway \\ Email: joakim.parslow@gmail.com
}

\begin{abstract}
Turkey's 1960 military coup d'état was received by Kemalists in the courts, bureaucracy, and universities as an opportunity to reinvigorate Atatürk's ideal of a centralized and rationally organized state. This article investigates how a handful of avant-garde thinkers sought to ride the post-1960 wave of reformism by promoting a techno-utopian approach to governance through publications and seminars aimed at state leaders and intellectuals. Cybernetics, they argued, offered a paradigm of adjudication and administration unblemished by association with the ascendant ideologies of the Cold War, whether socialist or conservative, and was fully in keeping with Kemalism. I argue that, although it remained largely at the stage of fantasy, Turkish cybernetics ultimately served as a set of metaphors with which conservative state thinkers from different political camps found common ground, facilitating the shift that occurred within the state during the 1970s away from the rights-based pluralism of the Constitution of 1961 and toward an effort to de-radicalize Turkish society, if necessary through violence.
\end{abstract}

Keywords: cybernetics; intellectual history; law; technoscience; Turkey

On 1 October 1973, just days before civilian government returned to Turkey after more than two years of martial law, a group of lawyers and information scientists gathered for a seminar under the auspices of the Istanbul Bar Association. The seminar brought to fruition a unanimous decision taken the previous year during the First Turkish Law Congress, at which legal scholars, attorneys, judges, and government officials had met to debate, among other things, how Turkey's legal system could be reformed to prevent a recurrence of the political crisis that led to the March 1971 military coup d'état. But the 1973 seminar made a dramatic departure from discussions of constitutional checks and balances and appeals courts. It was devoted to "cybernetics and the use of electronic brains in law."

Topics ranged from the practical to the futuristic. On the practical end, participants expressed an interest in using digital databases to improve the inconsistent record-keeping practices of Turkish courts. Because entering, retrieving, and visualizing records required, at the least, a keyboard or punch card device, a physical storage medium, a processor, and a printer or video terminal, discussion also turned to the assemblage of hardware still widely referred to as the electronic brain (elektronik beyin). The use of this organic metaphor rather than kompüter or the recently coined neologism bilgisayar (data computer) reflected the interests of the seminar's initiator, Toygar Akman. Municipal lawyer, philosopher, playwright, and theorist of cybernetics, Akman was less concerned with storing court records than with thinking through the momentous implications cybernetics might have for Turkish society. Fully taking advantage of electronic brains, he argued, could extend the cognitive capabilities of lawyers, judges, and state leaders beyond what was humanly possible, ultimately enabling the legal system to predict future violations of the law and even to replace courts with automated judging machines that would quickly produce perfectly uniform rulings, thereby preventing both a backlog of cases and the persistent problem of conflicting appellate rulings.

\footnotetext{
(c) The Author(s), 2021. Published by Cambridge University Press. This is an Open Access article, distributed under the terms of the Creative Commons Attribution-NonCommercial-NoDerivatives licence (https://creativecommons.org/licenses/by-nc-nd/4.0/), which permits non-commercial re-use, distribution, and reproduction in any medium, provided the original work is unaltered and is properly cited. The written permission of Cambridge University Press must be obtained for commercial re-use or in order to create a derivative work.
} 
Despite its air of science fiction, the seminar attracted sufficient attention among high-level officials that a second, larger conference on "cybernetics and law" was organized in Ankara the following year, with delegates from the Constitutional Court, the Union of Turkish Bar Associations, and the Ministry of Justice, as well as Turkish and foreign legal scholars and technologists. In reaching these echelons, Akman was aided by the ambiguity at the core of cybernetics. Both more and less than a conventional scientific discipline, cybernetics in its heyday in the 1950s and 1960s can be described as a "nomad science" that traversed disciplinary boundaries and made surprising connections across different genres of thought. ${ }^{1}$ Although most of its component concepts can be traced much farther back, it was the 1948 publication of Norbert Wiener's Cybernetics: Or Control and Communication in the Animal and Machine that popularized the paradigm. ${ }^{2}$ There, the American polymath narrated his efforts to develop an anti-aircraft system capable of predicting the path of a moving airplane during World War II, adopting terms from control engineering such as feedback, by which a system continuously adjusts its behavior in response to information from its environment, thereby maintaining its homeostasis, a balance of its basic parameter values. Generalizing these insights, Wiener and other theorists posited that self-regulating feedback systems could be found practically everywhere, from the simplest thermostat to complex organisms and ecosystems, exhibiting an "essential unity... whether in the machine or in living tissue." Wiener named the science of this universal dynamic cybernetics, adopting the Greek term for steersman, kubernétēs. After the war, cybernetics coalesced into a paradigm with a global reach and, crucially, metaphorical qualities that allowed scientists and governments to derive different and at times contradictory meanings from it while claiming that all these meanings sorted under "cybernetics."

In some countries, cybernetics became the touchstone for socially and politically relevant science, marking it as both universally valid and as immediately applicable to the most pressing issues of the day. The Cold War prompted a scientific arms race that funneled resources into cybernetic undertakings throughout the 1950s, extending the concept's impact far beyond military purposes. ${ }^{5}$ In the United States, Talcott Parsons integrated cybernetic concepts into his theory of societies as "social systems" whose parameters were determined by the requirement of maintaining homeostatic stability. ${ }^{6}$ His work inspired much Anglo-American work in sociology and political science throughout the 1950s and 1960s, from David Easton's theory of "political systems" to the science of engineering what Karl Deutsch called the "nerves of government."7 Theorists in Chile investigated how cybernetic methods might help peacefully realize democratic socialism, while in the USSR Khrushchev abandoned Stalin's suspicion toward the "bourgeois" science of cybernetics and sought to harness its power for vast reform programs. ${ }^{8}$ In several countries, from Brazil and France to the UK and the US, legal scholars began exploring the potential for automating the process of interpreting and applying the law, laying the foundations for what later became known as legal informatics. ${ }^{9}$

In Turkey, by contrast, cybernetics remained limited to very a small group of eccentric thinkers from the beginning of the 1960s until the early 1970s, when interest in its more extravagant claims had already

\footnotetext{
${ }^{1}$ Andrew Pickering, “Cybernetics as Nomad Science," in Deleuzian Intersections: Science, Technology, Anthropology, ed. Casper Bruun Jensen and Kjetil Rödje (New York: Berghahn Books, 2010), 155-62.

${ }^{2}$ Norbert Wiener, Cybernetics: Or Control and Communication in the Animal and the Machine (New York: Wiley, 1948). For the sources and context of Wiener's thought, see David A. Mindell, Between Human and Machine: Feedback, Control, and Computing before Cybernetics (Baltimore: Johns Hopkins University Press, 2002).

${ }^{3}$ Wiener, Cybernetics, 11.

${ }^{4}$ Geoffrey C. Bowker, "How to Be Universal: Some Cybernetic Strategies, 1943-70," Social Studies of Science 23, no. 1 (1993): 107-27.

${ }^{5}$ Paul N. Edwards, The Closed World: Computers and the Politics of Discourse in Cold War America (Cambridge, MA: MIT Press, 1996).

${ }^{6}$ Talcott Parsons, The Social System (London: Routledge \& Kegan Paul, 1951).

${ }^{7}$ David Easton, The Political System: An Inquiry into the State of Political Science (New York: A. A. Knopf, 1953); Karl Deutsch, The Nerves of Government: Models of Political Communication and Control (New York: Free Press, 1963).

${ }^{8}$ Slava Gerovitch, From Newspeak to Cyberspeak: A History of Soviet Cybernetics (Cambridge, MA: MIT Press, 2002); Eden Medina, Cybernetic Revolutionaries: Technology and Politics in Allende's Chile (Cambridge, MA: MIT Press, 2011); Adam E. Leeds, "Dreams in Cybernetic Fugue: Cold War Technoscience, the Intelligentsia, and the Birth of Soviet Mathematical Economics," Historical Studies in the Natural Sciences 46, no. 5 (2016): 633-68.

${ }^{9}$ Jon Bing, "Computers and Law: Some Beginnings," IT Information Technology 49, no. 2 (2007): 31.
} 
dwindled in much of the West. This lack of interest is not surprising in itself. Plenty of countries, from Egypt to India, remained on the sidelines of the postwar cybernetics vogue for any number of reasons. What is puzzling is that cybernetics abruptly caught on in Turkey after the 1971 coup d'état, and that, when it did gain traction, its pioneering Turkish theorists enjoyed a brief and intense period in the limelight, with judges and politicians from the highest levels of the Turkish state taking part in serious discussion of futuristic and fantastical visions that by that time were largely outmoded in Western cybernetic circles. What explains this sudden interest among statesmen who presumably had more pressing matters to attend to in a country shaken by political violence? Why did it dwindle so quickly during the late 1970s? More generally, what implications does this episode have for our understanding of the intersection of social science, technology, and governance during the turbulent decade of the 1970s?

In this article, I investigate the trajectory of cybernetic thinking in Turkey from the early 1960s, when Turkish theorists first began disseminating their ideas, to the early 1970s, when they briefly commanded the attention of the country's leaders. I argue that Turkey's short-lived cybernetics vogue can best be explained as a reaction to the political radicalization that swept Turkish society and its state institutions during the 1960s. The demographic transformations of the decade following the 1960 military coup upended the relative insularity of Turkey's urban elite and prepared the ground for the growth of radical left- and right-wing movements that both challenged the ideological legacy of Mustafa Kemal Atatürk and claimed it for themselves. ${ }^{10}$ Concerned with the rise of leftist radicalism in particular, and disillusioned with an increasingly influential cadre of leftist intellectuals and recalcitrant judges unwilling to silence them, leading statesmen sought a framework that was both scientific enough to challenge Marxist scholarship and sufficiently adaptable to fill the state's embattled official ideology, Kemalism, with new relevance. They found this framework in cybernetics, which Turkish theorists had eagerly promoted since 1960.

In the eyes of these theorists, the science of cybernetic systems synthesized and superseded established schools of thought to produce a paradigm unblemished by association with resurgent ideologies, whether socialist or conservative, secular or religious. For the same reason, they argued, cybernetics would enable a revitalization of the Kemalist state in an age when social complexities placed unprecedented demands on public administration. In the Kemalist imaginary, the modern Republic of Turkey-with its universities, its bureaucracy and courts, and its Armed Forces, which had defined itself as the guarantor of the political impartiality and stability of this entire edifice-was the institutional realization of the singular mind of Atatürk. Cybernetics provided a language for describing his vision as an embodied and operational yet nonhuman epistemology of governance, a form of total, mechanized administration that would fortify and extend the state's rationality by disengaging it from the cognitively inadequate and politically fractious humans that threatened to dismantle it. In short, Turkish cybernetics adapted Kemalism to the atomic age.

Remarkably, it did so despite remaining largely at the stage of fantasy. As Peter C. Caldwell has demonstrated, scientists and intellectuals in the German Democratic Republic turned to cybernetics in part because it offered them a language for critiquing social, political, and economic problems in a way that appeared compatible with the Marxist-Leninist tradition. ${ }^{11}$ Similarly, I argue, cybernetics appealed to Turkish state leaders, not because they truly believed that the state's political and judicial operations would soon become fully automatic, but because it provided a language for describing an ideal state that resonated with themes central to Kemalist state thinking such as science, progress, and organic unity. In making this argument, I follow historians of science such as Marwa Elshakry and Cyrus Schayegh, whose studies of the adoption of Western evolutionary and medical concepts in Egypt and Iran respectively eschew positivistic narratives of scientific "progress" in favor of a focus on the sociocultural contexts in which theories were appropriated and reframed as stages in those countries' own selfpropelled development. ${ }^{12}$ Viewed from this angle, the significance of the content of scientific theories becomes subordinated to the uses to which those theories are put by domestic intellectual and spiritual

\footnotetext{
${ }^{10}$ Berna Pekesen, ed., Turkey in Turmoil: Social Change and Political Radicalization during the 1960s (Oldenburg, Germany: De Gruyter, 2020).

${ }^{11}$ Peter C. Caldwell, Dictatorship, State Planning, and Social Theory in the German Democratic Republic (Cambridge, UK: Cambridge University Press, 2003).

${ }^{12}$ Marwa Elshakry, Reading Darwin in Arabic, 1860-1950 (Chicago: University of Chicago Press, 2013), 7; Cyrus Schayegh, Who Is Knowledgeable Is Strong: Science, Class, and the Formation of Modern Iranian Society, 1900-1950 (Berkeley, CA: University of California Press, 2009), 4.
} 
elites, by emergent social classes-or, in the case of Turkey, by political adversaries in search of a platform on which to build an alliance against a common enemy.

For Turkish statesmen worried about the integrity of their state, cybernetics had in common with much of what Hunter Heyck calls "high modern" social science its treatment of conceptual dichotomies as "signs of flawed thinking" that could be overcome with a sufficiently holistic framework. ${ }^{13}$ In place of the resurgent political cleavages of early 1970s Turkey_right and left, working class and bourgeoisie, city and countryside-cybernetics offered a politically sanitized distinction between the system and its environment, redefining governance as a process of information management. It was thus in part the indeterminacy of the cybernetic endeavor, and in part its emphasis on unity and synthesis, that made it a useful assemblage of metaphors for statesmen concerned with salvaging a state that was coming unglued. As we will see, these qualities allowed even conservative religious thinkers to embrace cybernetics as a science compatible with Islam without forgoing their commitment to their preexisting ideological position. At a fleeting but crucial moment, then, Turkish cybernetics became a focal point around which thinkers from different political camps found common ground, facilitating the broader shift that occurred within the state during the 1970s away from the rights-based pluralism of the Turkish Constitution of 1961 and toward an effort to de-radicalize Turkish society.

Yet the flexibility of cybernetics also facilitated an insidious confluence of authoritarian repression and theoretical escapism. As Jon Agar has argued, for the engineers of the Constitution of the United Statesmore commonly known as the founding fathers-mechanical metaphors of governance "were a means of making constitutional connections explicit, often at moments of tension." ${ }^{14}$ Similarly, cybernetics was in some respects a mechanical metaphor in that it rearticulated the familiar workings of the Turkish state - elections, budgeting, prosecution, judicial review-as the operations of a machine. But in contrast to physical mechanics, cybernetics translated material processes into flows of abstract information structured through software-like scripts that could reconfigure themselves to adapt to an unpredictable environment. This immateriality made cybernetics uniquely suitable for envisioning stability in a time when many of the concrete individuals and groups that populated state institutions were abandoning classical Kemalist notions of science-based governance in favor of revolutionary mass mobilization. But it also was attractive, I suggest, because it offered leaders a way of not speaking about the physical violence that the Turkish state was in the process of addressing to bring its institutions closer to the ideal of an apolitical apparatus of administration. Whereas much of the theorization of the period manifested a creative, optimistic approach to technology, the introduction of cybernetic thinking into Turkish state circles also signaled a longing for a disembodied and therefore morally and politically unassailable position of governing beyond the distinction between friend and enemy, rights-bearing legal subject and torturable bare life.

\section{A Giant Step}

In October 1964, a few days after Soviet cosmonauts had successfully returned from the first multi-crew spaceflight, the Turkish newspaper Milliyet (Nationality) published an op-ed by a 55 -year-old management consultant named Ali İrtem. İrtem worried that Turkey was lagging behind the developed world in embracing cybernetics, the latest scientific paradigm. In America, he noted, "sociologists, biologists, engineers, physicists, and mathematicians are all affected by cybernetics, while philosophers, artists, politicians, merchants, and staff officers all find themselves within it." After leading the reader through the basics of cybernetics he discussed the wide applicability of homeostatic principles to machines such as refrigerator thermostats and autonomous robots. Concluding that the time to rely on "natural brains" was over, he asked whether countries like Turkey, which he argued had slept through the industrial revolution-the revolution that had "replaced muscular power with machine power"-must once again remain a "distant and disinterested observer of this new and stunning cybernetic revolution, which is replacing the human brain with machine brains?"15

\footnotetext{
${ }^{13}$ Hunter Heyck, Age of System: Understanding the Development of Modern Social Science (Baltimore: Johns Hopkins University Press, 2015), 38.

${ }^{14}$ Jon Agar, The Government Machine: A Revolutionary History of the Computer (Cambridge, MA: MIT Press, 2003$), 25$.

${ }^{15}$ Ali İrtem, “Toplum Hayatında Büyük Bir Devrim,” Milliyet, 16 October 1964.
} 
The 1964 op-ed was not the first time İrtem had attempted to apply scientific principles to making Turkey a better place to live. The son of the revolutionary Young Turk bureaucrat Süleyman Kani İrtem and Fatma Sabite of the prominent İpekçi family, İrtem was born in Salonika in 1909, three years before the Ottoman Empire lost the city in the first Balkan War. ${ }^{16}$ While his father went on to serve as Vali (governor) of Istanbul during the Young Turk regime and then as the director of the Feyz-i Sibyan high school and historian during the early Republican years, Ali attended the Kabataş high school and subsequently studied technical physics in Berlin. ${ }^{17}$ In 1943 , the newspaper Tanin (Echo) published a curious text in which İrtem, writing under a pseudonym, presented mathematical equations which he claimed represented the different ways in which Easterners and Westerners conceived of happiness. In the East, he argued, happiness consisted of minimizing desire-best exemplified by the concept of Nirvana-whereas in the West it consisted of maximizing attainment of the object of desire, an approach lamentably illustrated by the Europeans. Although the latter strategy never led to true happiness, the former had made the East weaker than the West; for "us Anatolians," he argued, it might be best to temporarily adopt the Western approach while taking care not to forget the Eastern one. ${ }^{18}$

It was only in the early 1960s that İtem began developing arguments for a cybernetic approach to all of Turkey's societal ills. In 1960, he published an overview of cybernetics in a handbook on neurology edited by the psychiatrist Ayhan Songar. ${ }^{19}$ The chapter built largely on the work of Norbert Wiener and Ross Ashby, and touched on many of the themes that İrtem would elaborate over the following years, from the meaning of life to military strategy. He went on to publish several articles explaining how cybernetics might revolutionize neurology, robotics, and the social sciences in the Istanbul University medical faculty's journal of psychiatry Symposium, which Songar had founded. Meanwhile, he attempted to disseminate his happiness equations, now reinterpreted as the variables of a cybernetic amplification system, presenting an English translation of his paper at international conferences and even pitching it to Warren McCulloch and to Norbert Wiener himself. ${ }^{20}$

Political circumstances in addition to İrtem's personal background encouraged him to bring his ideas to a wider public. Turkey's deepest political crisis since the War of Independence coincided with his first forays into cybernetics. The country's founding father, Mustafa Kemal Atatürk, had been gone for little more than two decades, during which time his successors on the left and right had fought over the meaning of his legacy. Until the end of World War II, Kemalism, the official state ideology of corporate solidarity and state-led modernization, remained dominant thanks to an alliance of civil servants, academics, lawyers, and military officers loyal to the ruling Republican People's Party (Cumhuriyet Halk Partisi, hereafter RPP), which Kemal himself had founded. After the RPP was swept away in Turkey's first democratic elections in 1950 by the center-right populist Democrat Party (Demokrat Parti, hereafter DP), the Kemalists found their hegemony eroding in favor of businessmen, rural landowners, and social conservatives. Toward the end of the 1950s, the DP began responding to increasingly harsh criticism by dismissing public servants, censoring opposition media, and jailing journalists. Finally, in May 1960, Kemalist army officers took over government buildings and arrested hundreds of members of the DP, suspending

\footnotetext{
${ }^{16}$ Ali İrtem's family relations can be gleaned from a death notice in Cumhuriyet (23 November 1987, 3), and his date and place of birth are found in the short biography he provided for Jasia Reichardt, ed., Cybernetics, Art, and Ideas (London: Studio Vista London, 1971), 203.

${ }^{17}$ Ali İrtem, “İleri Hukukta Son Aşama: Sibernetik," İstanbul Barosu Dergisi 48, no. 1-4 (1974): 6; Marc David Baer, The Dönme: Jewish Converts, Muslim Revolutionaries, and Secular Turks (Stanford, CA: Stanford University Press, 2010 ), 195.

${ }^{18}$ Tufan Müneccimoğlu, "Doğu ve Batıda (Saadet) Telākkisinin Riyazi Bakımdan Mütaleası,” Tanin, 4 December 1943.

${ }^{19}$ Ali İrtem, "Sibernetik," in Sinir Sistemi Fizyolojisi III, ed. Ayhan Songar (Istanbul: Kader Matbaası, 1960), 667-707.

${ }^{20}$ American Philosophical Society Warren S. McCulloch Papers Mss.B.M139, Series 1, Correspondence, Box 12, İrtem to McCulloch, 6 August 1960, and İrtem to McCulloch, 28 January 1962. İrtem sent Wiener a copy of his 1960 book chapter in December that year along with "an old Turkish seal, as seasons greeting." The following year he sent a copy of his happiness paper and received a thank you card in response. Finally, in September 1962, he visited MIT and left a copy of the same article with a research assistant, who delivered it to Wiener with a note suggesting he read it "for its humorous or other value it might have" (Institute Archives and Special Collections, MIT Libraries, Cambridge, MA, Norbert Wiener Papers, MC22, Box 20 Folder 289, Box 21 Folder 306, and Box 34B Folder 1005). Others appear to have been similarly skeptical of İrtem's theory. New Scientist (no. 256, 1961, 118) notes that İrtem "suggested that machines might be devised to amplify happiness much as Professor Ashby has suggested that computers can amplify intelligence. Unfortunately, his definition of happiness was not one which could be universally accepted."
} 
the Constitution of 1924 and setting in motion the process that would lead to the establishment of the Second Republic.

That process was anything but simple. The coup was greeted by Kemalists in the army, courts, bureaucracy, and universities as an opportunity to reinvigorate Atatürk's ideal of a rationally organized and powerful state. But what Kemalists hailed as a "revolution" arising from popular demand to return the state to its rightful foundations in science and the rule of law, others saw as a coup d'état by an unelected elite anxious to restore the dominance it had enjoyed since the Young Turk era. The contradiction between the Kemalists' emphasis on "above-parties" (partilerüstü) institutions such as the Army, the judiciary, and the universities, and the fact that precisely those institutions had cooperated in ousting an elected government, exposed the interim regime to disagreement over the proper balance between expertise and democratic participation in the new constitutional order that was taking shape. Although some of the officers advocated establishing an authoritarian one-party system in the style of Gamal 'Abd al-Nasser's Egypt to carry out five-year development plans without interference from politicians, the dominant faction favored returning power to civilians. Eventually a radical group of officers who wanted to maintain military rule to carry out deeper structural reforms was ousted by moderates who wanted a swift return to elections. One of the ousted officers, Talat Aydemir, organized coup attempts in 1962 and 1963, both of which failed.

Although the danger of a second military takeover was averted, an increasingly youthful and politically mobilized urban population continued to feed state leaders' anxieties over the integrity of the state. By 1963, the universities that furnished the state with future bureaucrats and lawyers had become politically polarized to the point that fights broke out during student association meetings. ${ }^{21}$ Radical politics soon spread to other sectors of society. Conservatives among both the Kemalists and the populist center right attempted to stem the tide of socialism by prosecuting leftist intellectuals, but were often frustrated by left-leaning judges. Most worrying for conservatives were the efforts by leftist publications such as Ant (Oath), Yön (Direction), and Devrim (Revolution) to reinterpret Kemalism as a revolutionary socialist ideology in an attempt to provoke the Army to carry out another 1960-style coup. ${ }^{22}$ When military cadets began showing signs of political unrest, generals began pushing to expand the jurisdiction of peacetime military courts to include certain political crimes. ${ }^{23}$

İrem saw these tensions between reformists and revolutionaries as symptoms of an obsolete conception of social order. For him the solution to the unrest was neither more military dominance nor a second revolution; what Turkey needed was governance more attuned to the latest advances in technology. İrtem was not alone in trying to prod state leaders toward a more technoscientific approach to public administration. Soon after the 1960 coup, the Army's National Security Council (Milli Güvenlik Kurulu) established the State Planning Organization (Devlet Planlama Teşkilatı, DPT) and initiated the "Project for Researching the Organization of the Central Government" (Merkezi Hükümet Teşkilatı Araştırma Projesi, MEHTAP), which was carried out by the Institute of Public Administration for Turkey and the Middle East (Türkiye ve Orta Doğu Amme İdaresi Enstitüsü, TODAİE). Led by a commission of Ankara-based experts in public administration from both sides of the aisle, MEHTAP approached the Turkish state as a bureaucratic machinery that should, in its ideal typical form, contain no overlapping jurisdictions, gaps, or bottlenecks that would impede efficient and rational governance. ${ }^{24}$ Given this ideal, the most surprising aspect of MEHTAP was its lack of interest in computers as a tool of administration, despite the fact that the DPT was playing an instrumental role in acquiring the technology for Turkish universities and banks. In January 1965, Bülent Daver, a jurist at Ankara University, argued in Milliyet that, although the authoritarian developmentalism pursued by radical segments of the intelligentsia was not suited to Turkey, simply being democratically elected did not a good state leader make. What the country really needed, Daver argued, were leaders who grasped the complexities of an era of cybernetics

\footnotetext{
${ }^{21}$ Cumhuriyet, 4 January 1963; Yeni İstanbul, 3 and 12 December 1963.

${ }^{22}$ Özgür Mutlu Ulus, The Army and the Radical Left in Turkey: Military Coups, Socialist Revolution and Kemalism (London: I. B. Tauris, 2011), 44.

${ }^{23}$ Cumhuriyet, 23 February 1968.

${ }^{24}$ The MEHTAP commission included among its members Mümtaz Soysal and Süleyman Demirel. For a contemporaneous analysis of MEHTAP, see Clement Henry Dodd, “Administrative Reform in Turkey," Public Administration 43, no. 1 (1965): 7183.
} 
and automation: "if not exactly a scientist," at least an expert "manager elite" who understood the "languages of IBM" and approached statecraft as a "big statistics program."

Knowingly or not, Daver's comments echoed a far more radical proposal İrtem had made at a TODAİE seminar two months earlier and subsequently published in Symposium. ${ }^{26}$ Addressing an audience of political scientists and civil servants, İrtem argued that Turkey's economic underdevelopment was pushing engineers and intellectuals to emigrate to more advanced countries. This brain drain would eventually have an effect on society similar to an atomic bomb, leaving Turkey without any capable leaders. Faced with this vicious circle, some were asking themselves: "Cannot even Mustafa Kemal save us now?" İrtem's answer was "No": not simply because Atatürk was gone, but also because it would be impossible to create a sufficient number of new leaders with his extraordinary capabilities to meet the demands of Turkey's ballooning population. Instead, İrtem urged reformers to recognize the inevitable: "Whoever governs Turkey today, tomorrow it is cybernetic machines that will govern."

What followed was a detailed exposition of İrtem's vision for a project he called the "Giant Step" (Dev Adım), an abbreviation of his project's aim: the "Production of Statesmen" (DEVlet ADamı IMalı) that would fill the gap between the growing demands of Turkish society and the limited capabilities of the merely human leaders in whose hands Atatürk had entrusted it. Explaining the basics of Ross Ashby's mathematical formulae, İrtem argued that the state could be conceptualized as a cybernetic system, the stability of which required keeping its basic variables in balance in response to changes in its societal environment. Just as human state leaders might make decisions to maintain order according to existing laws, an artificial statesman machine would automatically adjust the state's variables to ensure that fluctuating markets, population growth, social unrest, and other disturbances did not threaten the system's integrity. Although the advanced materials required to develop the hardware out of which such a selfmodifying system would have to be built did not yet exist, taking advantage of cybernetics, he concluded, "appears to be the only way out." 27

\section{Shock Treatment}

As a rhetorical strategy, describing the statesman machine as the cybernetic incarnation both of a generically modern state's basic institutions and of Mustafa Kemal Atatürk, the revolutionary leader credited with bringing Turkey into the realm of political modernity, can be seen as an attempt to present cybernetics as what Star and Griesemer call a "boundary object," an object "both plastic enough to adapt to local needs and the constraints of the several parties employing [it], yet robust enough to maintain a common identity across sites." ${ }^{28}$ On the one hand, İrtem was appealing to information scientists as well as to lawyers, judges, and other state leaders concerned with the rule of law by describing the modern Turkish state as the equivalent of a computer with an operating system and software (its constitution and statutes), an input and feedback mechanism (elections, social demands), and a processor (the administration) continually reacting to the outside world and thus acting as an automatic and unwavering apparatus of governance. By coordinating its decisions, controlling their application, and continuously amending its software - that is, its laws-in response to feedback, the computer state also would take over the functions of a legislature and become what İtem called a "National Assembly and Senate machine." 29

But İrtem was eager to demonstrate that cybernetics also was useful in times of crisis, when the state's ordinary mode of operation prevented it from adapting fast enough to forestall a systemic breakdown. Such circumstances, he argued, were prevalent not only in "underdeveloped" countries such as his own; even "state machines" in advanced countries were coming under pressure. ${ }^{30}$ Here İrtem's invocation of Atatürk anchored the statesman machine in the context of a country still coming to terms with the

\footnotetext{
${ }^{25}$ Bülent Daver, "Rol ve Lider," Milliyet, 18 January 1965.

${ }^{26}$ Ali İrtem, "Devlet Adamı İmali (Dev Adım Projesi)," Symposium 4, no. 2-3 (1965): 29-44.

${ }^{27}$ Ibid., 36.

${ }^{28}$ Susan Leigh Star and James R. Griesemer, "Institutional Ecology, 'Translations' and Boundary Objects: Amateurs and Professionals in Berkeley's Museum of Vertebrate Zoology, 1907-39,” Social Studies of Science 19, no. 3 (1989): 393.

${ }^{29}$ İrtem, "Devlet Adamı İmalı." 31.

${ }^{30}$ Ibid.
} 
1960 military coup, which had indeed resulted in a systemic reset in the shape of the 1961 constitution. Citing his own 1963 Symposium article "Democracy from the Perspective of Nervous System Physiology," he indicated that such situations might require a form of "shock treatment." ${ }^{31}$ Precisely what İrtem meant by shock treatment is unclear; like many systems theoretical concepts, its abstraction enabled him to recommend it as the cybernetic equivalent to very different kinds of unconstitutional intervention. Indeed, over the following five years, İrtem would gradually broaden the term to encompass more blatantly authoritarian suspensions of the constitutional order. In the 1963 article, he had drawn inspiration from an article on electroconvulsive therapy from the American journal Electronics World and reproduced a diagrammatic illustration of a human head receiving electricity from a time-delay circuit (Fig. 1). ${ }^{32}$ In terms of cybernetic engineering, İrtem saw such shock treatment as a temporary and partial blockage of communication between units in a cybernetic system. Translating his cybernetic take into judicial terms, he described shock treatment as "partial censorship" within a system, in effect a suspension of the ordinary democratic process to facilitate quicker adaptation when social demands threatened to overload the system with feedback. ${ }^{33}$ Although he admitted that censorship sounded like a method "used by dictators," he argued that, cybernetically considered, it was simply a remedy for "social nervous disease." ${ }^{34}$ He described shock treatment in similar terms in an article for the Silahl Kuvvetler Dergisi (Journal of the Armed Forces) in December 1965, noting that even the United Kingdom, the "cradle of democracy," had applied censorship during World War II. ${ }^{35}$

Developments over the following years provided ample opportunity for İtem to link his cybernetic concepts to specific events and actors in Turkish society. In particular, he maintained an interest in selling his services to the Turkish Armed Forces. It is likely that İrtem's interest in military applications of cybernetics was born more from the industriousness of a freelance management consultant than from a political position on Turkish civil-military relations. ${ }^{36}$ In 1964 he corresponded with the multidisciplinary British scientist Gordon Pask, to whom he proposed development of "a device that could teach Turkish soldiers reading of the Turkish alphabet," and his 1965 article in the Silahl Kuvvetler Dergisi showed how cybernetics could be used for automatic translation, training, and a host of other military purposes. $^{37}$ The same year, İrtem followed up Bülent Daver's text with a Milliyet op-ed in which he extended the promise of cybernetics to encompass "military machines" that would be "capable of identifying strategies on their own." ${ }^{38}$ Whatever his intention, however, the effect was to promote cybernetics as a framework for understanding state-society relations that appeared to make distinctions between ordinary law and emergency law, and civilian and military concerns, irrelevant. Like Atatürk, İrtem's statesman machine combined the functions of revolutionary war hero and visionary peacetime reformist, and was capable both of everyday governance within a constitutional framework and of suspending that framework in times of crisis.

The martial dimension of İrtem's statesman machine increased over the following years, as leftist students and workers began clashing with riot police and right-wing "commando" groups on a weekly basis. In October 1968 İrtem addressed the uprisings in an op-ed in the leftist-Kemalist newspaper Cumhuriyet (Republic), arguing that, whereas Turkish leaders saw the uprisings as a purely economic matter, in developed countries such turbulence was grasped in a wider "cybernetic" sense. ${ }^{39}$ Most importantly, the development of intelligent machines was rendering the question of finding adequate leaders to address the demands of alienated youth moot, as such problems would soon be left to cybernetic systems. Six months

\footnotetext{
${ }^{31}$ Ali İrtem, "Sinir Sistemi Fizyolojisi Bakımından Demokrasi," Symposium 2, no. 2 (1963): 132-40.

${ }^{32}$ Ed Bukstein, "Electric Shock on Purpose," Electronics World (February 1963).

${ }^{33}$ İrtem, "Sınır Sistemi Fizyolojisi Bakımından Demokrasi." 139.

${ }^{34}$ Ibid.

${ }^{35}$ Ali İrtem, “Sibernetik (Bütün Bilgi Kolları Arasında Köprü),” Silahlı Kuvvetler Dergisi 84, no. 216 (1965), 71.

${ }^{36}$ İtem describes himself as a "Management Consultant" on the business card he left for Norbert Wiener at MIT in 1962.

${ }^{37}$ University of Vienna Gordon Pask Archives 3.4.2.1.10.5; İrtem, “Sibernetik (Bütün Bilgi)." In 1972, İrtem also pitched cybernetic statecraft in a lecture at the War Academies Commandorship (Harp Akademileri Komutanlı̆̆ $)$ at Yıldız Palace in Istanbul. Ali İrtem, Sibernetik: II. Sanayi Devrim (Bütün Bilim ve Teknik Dallarını Kapsayan Büyük Devrim) (Istanbul: Harp Akademileri Komutanlığı Yayınlarından, 1972).

${ }^{38}$ Ali İrtem, "Dünyayı Yakın Bir Gelecekte Makineler İdare Edecek," Milliyet, 25 February 1965.

${ }^{39}$ Ali İrtem, "Gençlik ve Sibernetik," Cumhuriyet, 8 October 1968.
} 




Figure 1. A time-delay circuit for electroshock treatment. From Ed Bukstein, "Electric Shock on Purpose," Electronics World (February 1963): 33, reproduced in Ali İrtem, "Sinir Sistemi Fizyolojisi Bakımından Demokrasi," Symposium 2, no. 2 (1963): 133.

later, he brought ideas he had presented to the TODAİE reformers to a wider public in a Cumhuriyet article titled "The Manufacture of Statesmen and Cybernetics." 40 This time, he appealed to those who were seeking a new revolutionary leader, a new Atatürk to, as law professor Bülent Nuri Esen put it, "bring 1960 to its completion." ${ }^{41}$ The lesson to take from Atatürk, İrtem argued, was not simply to "walk in his footsteps" as so many claimed to be doing; in addition, Turks must heed his call to "add new revolutions to the old ones." The most promising such revolution was cybernetics, which would extend humanity's intelligence much the same way the industrial revolution had extended its muscular power. Just as Mustafa Kemal had brought Turkey into the 20th century, he concluded, a cybernetic statesman machine would bring it into the atomic age.

The statesman machine İrtem was envisioning was thus both a conservative and a disruptive force; it could maintain systemic stability and, when circumstances required it, reset itself by administering "shock treatment." It was this ambiguity that allowed İrtem to appeal to both sides of the political landscape as polarization continued to intensify toward the end of the decade. Süleyman Demirel, who had served on the MEHTAP commission in 1961-63 before taking up the chairmanship of the Adalet Partisi (Justice Party), the successor party to the deposed DP, became prime minister in October 1965. In March 1970, while his government was pushing to shut down the radical labor syndicate DİSK, İrtem offered readers of Cumhuriyet a graphic representation of an electromagnetic problem-solving circuit, which included a mechanism for alerting the user when a disturbance occurred that the system would be unable to solve through ordinary means. ${ }^{42}$ Applied to societal governance, he argued, this "revolution warning machine" could notify state leaders when upheavals similar to a "French revolution" or a "War of Independence" was underway. Lest readers think İrtem was taking the side of conservatives, in his next column in May

\footnotetext{
${ }^{40}$ Ali İrtem, "Devlet Adamı İmali ve Sibernetik," Cumhuriyet, 19 March 1969.

${ }^{41}$ Bülent Nuri Esen, “Güzel Dersler," Cumhuriyet, 29 June 1969.

${ }^{42}$ Ali İrtem, "Sibernetik ve İhtilali Haber Verme Makinası," Cumhuriyet, 7 March 1970.
} 
1970 he noted that even Soviet leaders had embraced it as the basis of the "new social structure that is being established." ${ }^{33}$ Instead of putting society through violent turmoil, he argued, such mechanisms could be used to "simulate" revolutions to find solutions to problems caused by "self-seeking" (çıkarcı) elected leaders-an obvious reference to the Justice Party government, to which Cumhuriyet was opposed. Instead of simply relying on "electoral administration," he continued the following month, one might construct a "constitutional laboratory" where the effects of different legal structures could be measured before they were put into practice. ${ }^{4}$

Just one week after İrtem's column appeared, tens of thousands of workers took to the streets, bringing Istanbul to a standstill in protest of Demirel's attempts to destroy DİSK. The protest sent panic through the conservative camp, which described it as a "dress rehearsal for a Communist revolution." ${ }^{45}$ The government declared martial law and called in the army, which rounded up hundreds of workers and student activists and tried them in military courts. Three months later, İrtem returned to the issue of social unrest. ${ }^{46}$ Having already suggested a system for predicting revolt, he was now thinking through how even martial law-a suspension of ordinary rules of governance-could be incorporated into a governing machine through the concept of "shock treatment." In the US, he noted, the Air Force had financed research that aimed to develop a "legal mathematics" that would allow law to be "mechanized." To explain how cybernetic law might even help an unstable country such as Turkey, İrtem recounted a recent conversation with a British cyberneticist who was dismayed by Turkey's recourse to martial law, which he argued amounted to "temporarily administering shock treatment to a cybernetic system's nervous system." İrtem agreed that martial law, like censorship, constituted a form of shock treatment, but assured him that the Turkish Armed Forces were applying it carefully to prevent permanent damage to the system.

İrtem's defense of the martial law of the summer of 1970 placed him at odds with jurists in the leftist-Kemalist camp, who argued that it was an unconstitutional suspension of basic rights. Secure in his belief that cybernetics was superseding old political conflicts, he nevertheless addressed this last op-ed to "our valuable lawyers" with little regard for the political split that events had caused among them. For İrem, the universal validity of the principles of cybernetics meant that the abstract conceptual distinctions on which it was built-system versus environment, positive versus negative feedback-took precedence over the concrete political struggles and ideological allegiances of the merely contingent physical humans to which the science was applied. Perhaps sensing that his proposals were falling on deaf ears among an increasingly politicized Turkish public, he gave up publishing in major newspapers. As Turkey inched closer to a military coup over the following nine months, İrtem also largely abandoned his efforts to convince Turkish state leaders to take seriously his Giant Step. During the following years, he increasingly turned his attention to the deeper philosophical implications of cybernetics for understanding consciousness, attending cybernetics conferences around the world while venturing into philosophical territory that would now be recognized as transhumanism. ${ }^{47}$ But when İrtem began focusing his attentions on his fellow theorists abroad and less on Turkey's immediate problems, he left behind a space for discussion into which other cyberneticists stepped when the opportunity arose in March 1971. The most important of these for the following few years was Toygar Akman, an attorney, municipal bureaucrat, and philosopher (Fig. 2).

\section{The Judgment Machine}

Toygar Akman (1927-2011) began his career as a law student at Istanbul University, where he also developed an interest in psychology, psychiatry, and philosophy. ${ }^{48}$ After completing his law degree he began studying for a $\mathrm{PhD}$ in psychology under the German experimental psychologist Wilhelm Peters (1880-

\footnotetext{
${ }^{43}$ Ali İrtem, "Yeni Devrimler ve Sibernetik," Cumhuriyet, 15 May 1970.

${ }^{44}$ Ali İrtem, “Anayasa: Laboratuvar ve Sibernetik," Cumhuriyet, 7 June 1970.

45“Bir İhtilal Denemesi," Son Havadis, 24 June 1970; “Komünist İhtilalın Provası Yapılıyor," Son Havadis, 21 February 1971.

${ }^{46}$ Ali İrtem, "Hukuksal Devrim ve Sibernetik," Cumhuriyet, 2 November 1970.

${ }^{47}$ İrtem's 1963 conference paper on happiness amplification was eventually published in a book now considered a transhumanist cult classic alongside chapters by, among others, Greek composer Iannis Xenakis and British cyberneticist Gordon Pask: "Happiness Amplified Cybernetically," in Reichardt, Cybernetics, 72-75.

${ }^{48}$ A short biography of Akman in Türk Tiyatrosu 34, no. 360 (1964): 14-15, probably written by Akman himself, states that he followed classes in psychiatry and psychology more than the law classes he was signed up for at the university.
} 


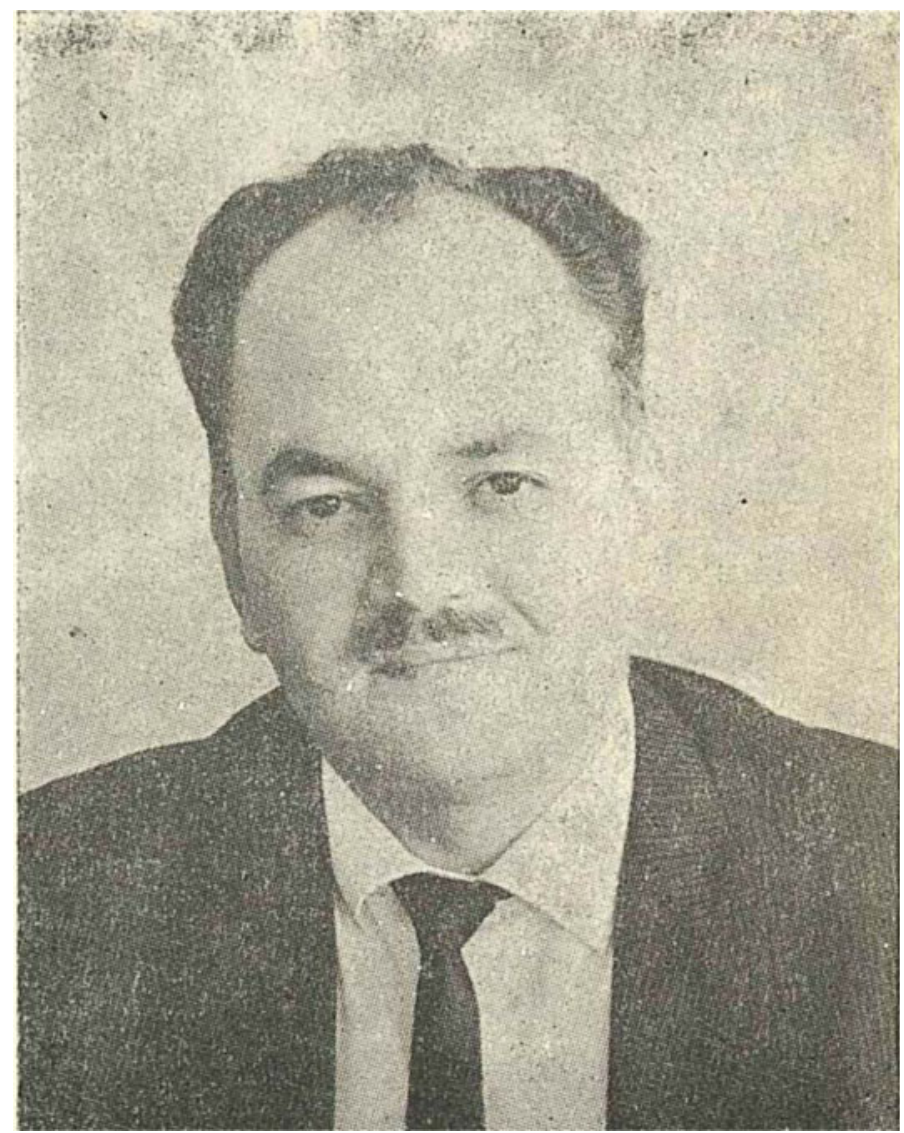

Figure 2. Toygar Akman. Türk Tiyatrosu, no. 260 (1964): 14.

1963), who had been living in exile in Istanbul since $1937 .{ }^{49}$ Returning from military service in 1951, Akman found that Peters had moved back to Germany, so he turned instead to the philosopher, sociologist, and intellectual historian Hilmi Ziya Ülken (1901-74) for supervision. ${ }^{50}$ Akman's $1971 \mathrm{PhD}$ thesis, Beşinci Boyut (The Fifth Dimension), was a wide-ranging discussion of human consciousness, synthesizing insights from philosophy, psychology, and cybernetics. ${ }^{51}$ While working on his thesis, he became the Istanbul municipality's Director for Legal Affairs and produced the weekly show Modern İlimde Gelişmeler (Developments in Modern Science) for the public Ankara radio channel.

Like İrtem, Akman contributed a chapter to Ayhan Songar's 1960 volume of neurology, in which he elaborated his views on the cybernetic nature of consciousness. ${ }^{52} \mathrm{He}$ also took his first steps in writing fiction. His science fiction play Elektronik Beyin (The Electronic Brain) was performed at the Istanbul Municipal Theatre at Tepebaşı during the 1964-65 season and was by Akman's own admission "not particularly successful." Nevertheless, it showcased his fascination for human-computer interaction and automation: The play's main character, the "scientist," builds a computer that runs entirely on his own brain waves; complications ensue as the machine falls in love with his fiancée. ${ }^{53}$

\footnotetext{
${ }^{49}$ Wilhelm Peters was dismissed from his position as the dean of the faculty of mathematics and natural sciences at the University of Jena in 1932 for being Jewish. He first emigrated to the United Kingdom before accepting an invitation to take up a position at Istanbul University.

${ }^{50}$ Ahmed Yüksel Özemre, Geçmiş Zaman Olur Ki (Istanbul: Kubbealti Neşriyat1, 1998), 502.

${ }^{51}$ Akman's thesis was eventually published as Beşinci Boyut (Istanbul: Karacan Yayınları, 1981).

${ }^{52}$ Toygar Akman, "Modern Fiziğin Getirdiği Realiteler ve 'Şuur' Problemi," in Sinir Sistemi Fizyolojisi III, ed. Ayhan Songar (Istanbul: Kader Matbaas1, 1960), 872-934.

${ }^{53}$ Toygar Akman, Elektronik Beyin (İstanbul Büyükşehir Belediyesi Şehir Tiyatroları Kütüphanesi, OMB 540). A synopsis and analysis of the play can be found in Joakim Parslow, "The Electronic Brain: A Missing Link in Turkish Science Fiction," in
} 
Although he credited İrtem with introducing cybernetics to Turkey, it was clear that Akman, as a registered attorney and high-ranking civil servant, was in a better position to carry İrtem's ideas about cybernetic governance into Turkish state circles. ${ }^{54}$ Ironically, what finally aroused the attention of leading statesmen was precisely the kind of "shock treatment" that İrtem had prescribed since the mid-1960s. On 12 March 1971, after an uptick in militancy on the radical left, the general staff handed Prime Minister Demirel a memorandum demanding that he either resign or establish a strong government capable of carrying out reforms "in a Kemalist spirit." Demirel resigned, and the generals appointed a cabinet of above-parties technocrats led by Nihat Erim, a jurist and former member of the center-left wing of the RPP. In April, the cabinet declared martial law and outlawed dozens of publications and associations while security forces detained thousands of leftist activists and intellectuals. Allegations of torture carried out by right-wing militants alongside security forces surfaced during the military trials that followed and grew stronger during and after the two years in which martial law was in effect.

This was the atmosphere in which, little more than a year after the military intervention, the Union of Turkish Bar Associations (Türkiye Barolar Birliği; TBB) held what it billed as the "First Turkish Law Congress." Local bar associations, courts, and government ministries sent delegations to discuss urgent matters such as the reform of legal codes, proposals to establish a new "Justice Academy" for aspiring judges, overloaded and inefficient courts, and the degeneration of the rule of law. On the list of speakers, which included jurists such as the recently retired Constitutional Court justice Salim Başol and several judges and prosecutors of the Court of Cassation and Military Court of Cassation, was Toygar Akman, who presented a paper titled "The Electronic Brain: Cybernetics and Law." 55

Assuming no prior knowledge of cybernetics among his audience, Akman discussed the etymology of the term and the early history of modern cybernetics before introducing the concept of homeostasis, which he took to be illustrative of the social function of law in society: to maintain a "balance of rights." He then discussed the binary code in which the cybernetic system receives its positive or negative feedback, and argued that all legal communication could be expressed in a similar form. But the core of his paper consisted of a diagrammatic illustration showing how a courtroom could be replaced by an "electronic judgement machine" (elektronik yargı makinesi; Fig. 3). At the head of the courtroom sat the "judge," whose function was to request and process feedback following a predetermined legal script. Facing the judge on the other end of the room sat the legal representatives of the two parties to a trial, who took turns responding to the judge's inquiries. In the middle of the diagram sat the "clerk," the human equivalent of an "automatic printer" whose function was to preserve a record of the communication-the only female figure in the illustration. ${ }^{56}$ Once in motion, the system would operate much like real-life courtroom proceedings reduced to a series of binary signals. The judge would request information such as the identity of the parties and the facts of the case, and would receive answers from the parties in a binary code, such as "yes" or "no." Once the judge had received all the information necessary to determine the facts, he would automatically apply the relevant statutes that were stored in the apparatus to make his decision.

Perhaps sensing that a representation of a courtroom stripped of all the materiality and ambiguity of a real-life trial might arouse skepticism among legal professionals, Akman responded to an imagined interlocutor who protested that "the science of law cannot be imagined within such a basic system!" Against this, Akman argued that the process of interpreting facts and evaluating evidence was just as logical as a computer language. Indeed, in his view, practically any task, from drafting to applying laws, would be more accurately carried out if left to "electronic brains." Even the enforcement of curfew during martial

Building Bridges to Turkish: Essays in Honour of Bernt Brendemoen, Turcologica 116, ed. Eva A. Csato, Joakim Parslow, Emel Turker, and Einar Wigen (Wiesbaden: Harrassowitz, 2018), 225-44.

${ }^{54}$ Toygar Akman, Sibernetik, Bilimde Devrim: Elektronik Beyin, Hukukda Reform (Ankara: Banka ve Ticaret Hukuku Araştırma Enstitüsü, 1972), 2.

${ }^{55}$ Toygar Akman, "Elektronik Beyin: Sibernetik ve Hukuk," in Birinci Türk Hukuk Kongresi’ne Sunulan Tebliğler, ed. Faruk Erem (Ankara: Türkiye Barolar Birliği, 1972), 3-61.

${ }^{56}$ In reproducing gender stereotypes in the form of computer hardware, Akman's courtroom echoed the work of British cyberneticist Stafford Beer, who in 1971 began work on the cybernetic planning system Cybersyn for the Chilean government. The heart of Beer's system was an operations room equipped with chairs designed for a team of male decision-makers, who could operate it directly through buttons on their armrests, thus eliminating the typist "girl between themselves and the machinery" (Beer cited in Medina, Cybernetic Revolutionaries, 127). 


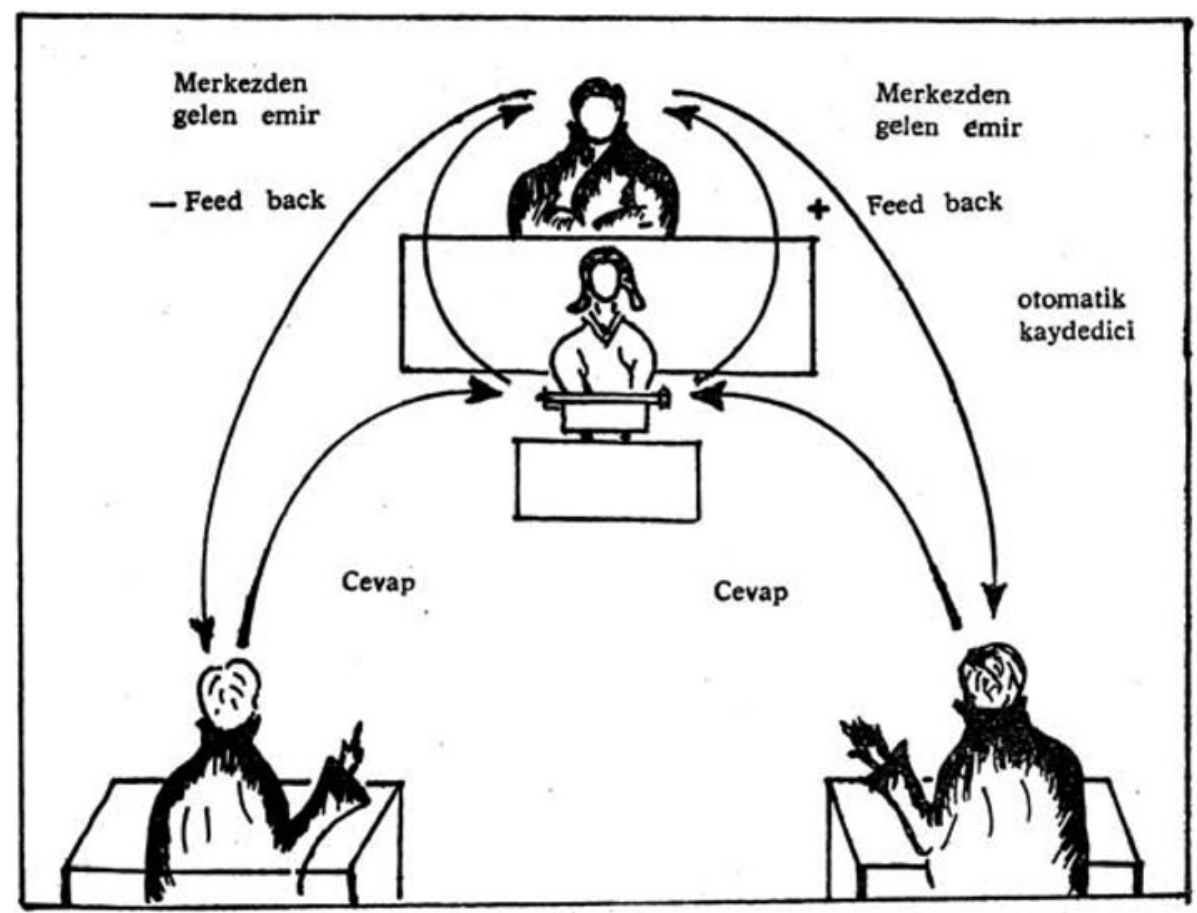

Figure 3. Toygar Akman's electronic judging machine. Toygar Akman, Sibernetik, Bilimde Devrim: Elektronik Beyin, Hukukda Reform (Ankara: Banka ve Ticaret Hukuku Araştırma Enstitüsü, 1972), 101.

law could be translated to a simple binary syntax of positive and negative feedback: positive when citizens were free to roam, negative when they had to remain indoors.

Akman's paper attracted serious interest among the attendees, although its precise implications appear to have been unclear. Yaşar Karayalçın, a specialist in business law, urged the TBB to take Akman's ideas seriously and to begin by implementing them to keep judicial registries so that "Turkish legal life does not experience the misfortune of lagging behind the Western countries"; similarly, Mustafa Tören Yücel from the Ministry of Justice stated that cybernetic computers should be adopted to analyze judicial statistics for criminological purposes. ${ }^{57}$ According to attorney Vedat Karadeli, the "cybernetic electronic brain and law" was "the most interesting topic taken up at the Turkish Law Congress." Because it would result in the quick and sound completion of trials, he argued, "we [should] consider the application of cybernetics and electronic brain systems to the judicial services a necessary topic of reform." 58 Accordingly the TBB made a unanimous resolution to urgently look into the application of computer systems and cybernetics. ${ }^{59}$

\section{Law and Violence}

Encouraged by the positive response, Akman quickly expanded his conference presentation in the book Sibernetik: Bilimde Devrim. Elektronik Beyin: Hukukda Reform (Cybernetics, a Revolution in Science: The Electronic Brain, Legal Reform), which was published later the same year. Akman's paper was here embedded in a meandering discussion of cybernetic themes, from his 1964 theater play to the different ways in which binary codes might be applied to construct a digital decision tree that could determine whether or not a specific act fulfilled all of the criteria constituting "theft" or some other legal violation. ${ }^{60}$

\footnotetext{
${ }^{57}$ Türkiye Barolar Birliği, 1. Türk Hukuk Kongresi Tutanağı, 23-25 Nisan 1972 Ankara, Türkiye Barolar Birliği Yayınları 3 (Ankara: Türkiye Barolar Birliği, 1972), 153, 140.

${ }^{58}$ Vedat Karadeli, “1. Türk Hukuk Kongresi ve Neticeleri," Ankara Barosu Dergisi, no. 3 (1972): 428-29.

${ }^{59}$ Türkiye Barolar Birliği, 1. Türk Hukuk Kongresi Tutană̆ $1,133$.

${ }^{60}$ Akman, Sibernetik, Bilimde Devrim, 112.
} 
He devoted a long section to discussing electroencephalography (EEG), the electronic monitoring of brain activity, which he argued would soon be used in the service of criminal investigations to determine whether a suspect was telling the truth. Akman had explored computer-brainwave interaction in his play, in which the "scientist's" computer reacted to his emotional state with blinking lights. Here, the same idea was put to use in the service of criminal justice: Akman argued it could replace narcoanalysis, or truth serum, which he noted that some jurists considered a form of torture. ${ }^{61}$

Akman did not, however, discuss the actual torture that newspapers such as Cumhuriyet were reporting from ongoing military trials. Much as his cybernetic rendition of martial law removed any hint of the "shock treatment" that the Turkish state was in the process of applying through sweeping arrests, torture, and eventually-twelve days after the conference had finished-the hanging of the militant leftists Deniz Gezmiş, Yusuf Aslan, and Hüseyin İnan, Akman's focus here was on demonstrating how the cybernation of the justice system could take the issue of justice out of the hands of fallible, misled, and sometimes brutal human beings, obviating any need for torture and executions. ${ }^{62}$ Although he stopped short of designing a fully integrated automatic system of detection, adjudication, and sanction, he gestured toward it at the end of his book, where he provided a short summary of his argument in English: "By the help of these systems, human use of human beings or human punishment of human beings will be done by computers instead of man." 63

Over the next two years, Akman became a regular contributor to the popular science journal Bilim ve Teknik (Science and Technics), where three of his articles were devoted to legal cybernetics. ${ }^{64}$ Meanwhile, cybernetics was catching on within wider circles. The June 1973 special issue of the news magazine Devir (Era) featured a futuristic "electronic brain" on its front page; inside, it showed Prime Minister Nihat Erim inspecting an IBM computer used by the police in Washington, DC, and discussed the new computer center at Ege University in İzmir, which housed one of the eighty-two computers in Turkey at the time (Figs. 4 and 5). ${ }^{65}$ At the same university, Sedat Akalın, a management and econometrics scholar, wrote an introductory book and several articles on cybernetics for the İstanbul Üniversitesi İsletme Fakültesi Dergisi (Istanbul University Journal of Management). ${ }^{66}$ Perhaps prodded by Ali İrtem's 1970 article on machine engineering and cybernetics in the journal Engineer and Machine, engineers also began taking an interest in the role technical experts should play in a politicized and economically underdeveloped country such as Turkey, one arguing that "the collapse of the bureaucracy would be much more advantageous than the collapse of technocracy." 67

In June 1973, the Istanbul Bar Association decided it was time to organize a seminar, called "Cybernetics in Law and the Use of Computers." ${ }^{68}$ The seminar was held over three days in October, and brought lawyers together with engineers, physicists, neurologists, and systems analysts. Following the seminar, Ali İrtem and professor of criminal law Öztekin Tosun contributed articles evaluating the seminar to a special issue of the Istanbul Bar Association's journal. The use of digital databases was among the topics taken most seriously by the attendees. According to Cumhuriyet, the conference revealed that Turkish courts' record-keeping practices were so poor that convicts had occasionally been punished twice for the same offence; others complained that the sheer number of statutes on the

\footnotetext{
${ }^{61}$ Ibid., 131.

${ }^{62}$ Gezmiş, Aslan, and İnan were members of the armed Marxist-Leninist Türkiye Halk Kurtuluş Ordusu (People's Liberation Army of Turkey) and were arrested in March 1971 and court-martialed for attempting to overthrow the constitutional order. Their death sentence was highly controversial, and was only carried out after months of appeals, political negotiations, and contestation between different judicial, legislative, and executive branches.

${ }^{63}$ Ibid., 211.

${ }^{64}$ Toygar Akman, "Yarg1 Makineleri," Bilim ve Teknik, no. 64 (1973): 44; Toygar Akman, "Sibernetik ve Hukuk," Bilim ve Teknik 78 (May 1974): 5-9; Toygar Akman, "Hukuksal Sibernetik,” Bilim ve Teknik 10, no. 114 (1977): 3-7.

${ }^{65}$ Devir, no. 32 (1973): 12.

${ }^{66}$ Sedat Akalın, Sibernetik (Izmir: Ticaret Matbaacılık, 1971); Sedat Akalın, "Sibernetik Eğitim,” İstanbul Üniversitesi İsletme Fakültesi Dergisi 1, no. 1 (1972): 117-29; Sedat Akalın, "Sibernetik: Yönetimsel Bir Yaklaşım," İstanbul Üniversitesi İşletme Fakültesi Dergisi 2, no. 1 (1973): 73-79; Sedat Akalın, “Denel Sibernetik,” İstanbul Üniversitesi İşletme Fakültesi Dergisi 3, no. 1 (1974): 93-97.

${ }^{67}$ Ali İrtem, “Makina Mühendisi ve Sibernetik,” Mühendis ve Makina 13, no. 156 (1970): 475-76; Ali Nejat Ölçen, "Bürokrat ve Teknokrat Çaprazı,” Elektrik Mühendisliği, no. 184 (April 1972): 23. See also Ali Gevgilili, “Türkiye’de Teknokrasi: Teknik Elemanın Türk Toplumundaki Sosyo-Ekonomik Konumu,” Türkiye Mühendislik Haberleri (May 1973).

${ }^{68}$ Milliyet, 23 June 1973.
} 


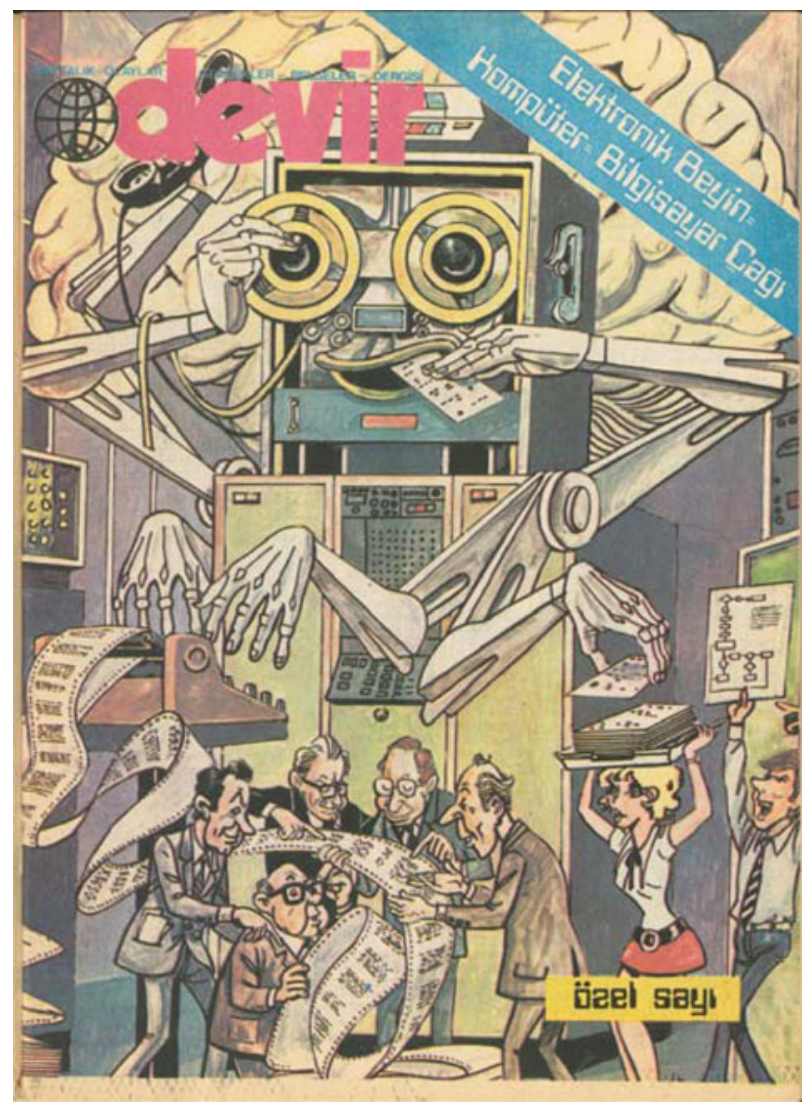

Figure 4. An "electronic brain" on the front page of the June 1973 special issue of Devir. The image was drawn by the caricaturist İsmail Gülgeç. From Devir, no. 32 (1973): 1.

books resulted in new laws being written on the basis of previously annulled statutes. ${ }^{69}$ Accordingly, Tosun's article was mainly concerned with how computers could solve the problem of overflowing judicial archives and speed up the work of judicial personnel by facilitating the storage and retrieval of large amounts of data, a point that attorney Enver Arslanalp developed in an article in Danıştay Dergisi (Journal of the Council of State). ${ }^{70}$ Ali İrtem's contribution was characteristically futuristic in comparison, and discussed how the ministries of justice, finance, economy, and education could be seen as societal equivalents to the four basic variables that Ross Ashby argued were present in any living organism. In both the organic and governmental senses, he argued, the four variables must be kept in balance through the continuous evaluation of feedback, otherwise the result might be "revolutions" (devrimler). ${ }^{71}$

Although the concerns of lawyers and cyberneticists appeared quite distinct from each other, state prosecutor Selçuk Bengü noted in Cumhuriyet that "in the end, lawyers and cyberneticists agreed! They liked each other very much, and who would think otherwise, since physics, mathematics and law were united in logic [mantık]. Who knows what the result will be?"72 From 28 to 31 January 1974, therefore, the Center for National Productiveness (Milli Prodüktivite Merkezi) held a follow-up seminar, "Cybernetics in Law and the Use of Computers," with the cooperation of the recently founded Turkish Informatics Association (Türkiye Bilişim Derneği). Among the participants were representatives of the bar associations, academic jurists, the presidents of the Court of Cassation (Yargitay) and the Council of State (Danıştay), and two experts from the Ministry of Justice. Present this time also were nonlawyers such as psychiatrist Ayhan Songar, several computer experts, and a delegate from the Austrian

\footnotetext{
${ }^{69}$ Cumhuriyet, 2 October 1973.

${ }^{70}$ Öztekin Tosun, "Sibernetik ve Hukuk," İstanbul Barosu Dergisi 48, no. 1-4 (1974): 21-25; Enver Arslanalp, "Hukuk Alanında Bilgisayar,” Danıştay Dergisi, no. 9-10 (1973): 97-108.

${ }^{71}$ İrtem, "İleri Hukukta Son Aşama."

${ }^{72}$ Selçuk C. Bengü, "Hukuk ve Elektronik Beyin,” Cumhuriyet, 6 September 1973.
} 


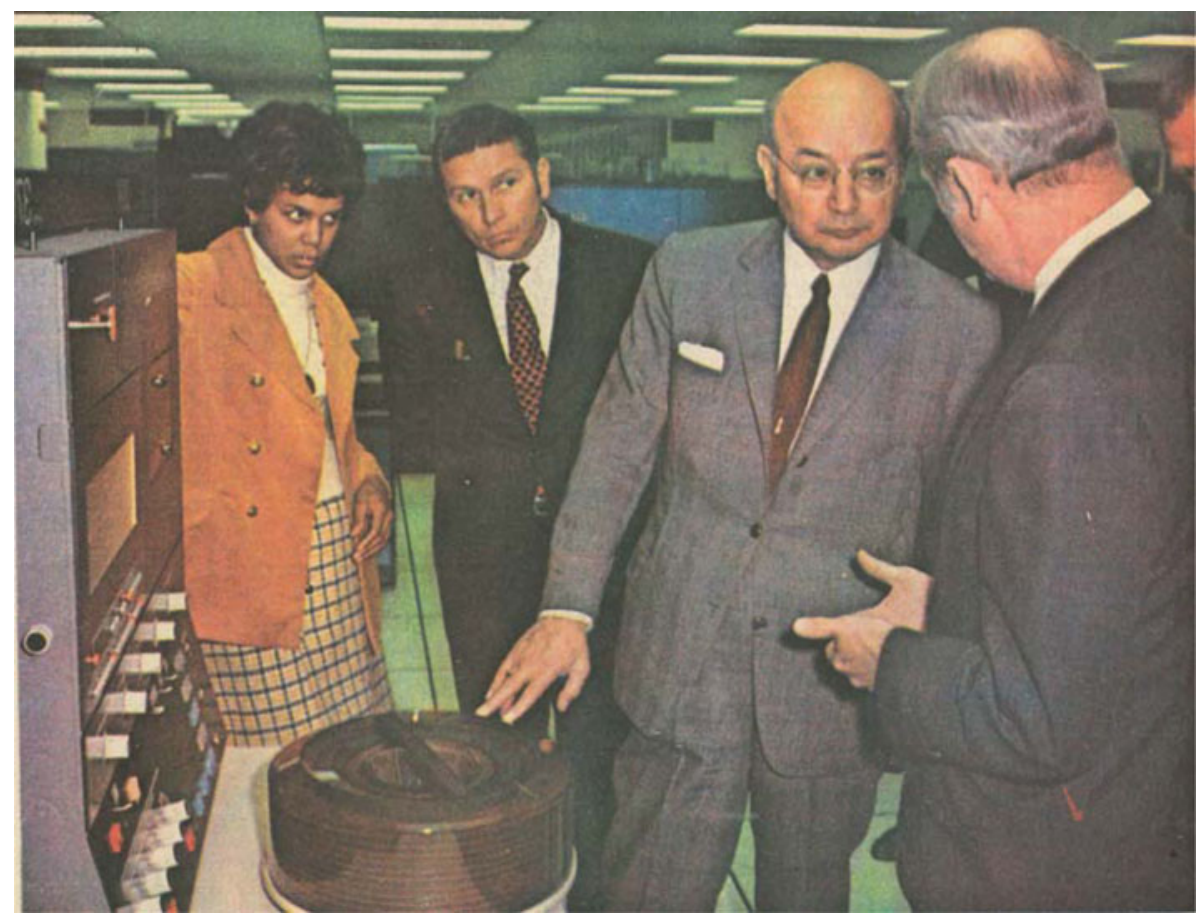

Figure 5. Prime Minister Nihat Erim learning about how the Washington, DC, police use IBM computers. From Devir, no. 32 (1973): 11.

Ministry of the Interior. Muhittin Taylan, the president of the Constitutional Court, gave the opening speech.

As with the 1973 seminar, many of the participants of the four-day conference saw computers as promising primarily from an archiving perspective. Selçuk Bengü, the enthusiastic prosecutor who had attended the previous seminar, argued that an electronic system for keeping criminal records would enable the state to centralize and systematize all of its data on convicts, preventing the "astronomic" buildup of paper files that were being stored and moved around. ${ }^{73}$ Similarly, Yekta Güngör Özden, the head of the Ankara Bar Association, suggested computers as a convenient medium for storing courtroom minutes. ${ }^{74}$

Others went further in envisioning how cybernetics might restore the esteem of the Turkish judiciary. Akman's contribution consisted of a paper he also published in the Danıştay Dergi on "Cybernetics and Machine-Human Cooperation." Having planted the seed for the conference in his presentation at the Turkish law conference two years prior, he devoted the first part of his essay to discussing how his ideas had been received by Turkish lawyers, before delving into a detailed discussion of how cybernetics could automate the laborious process of ensuring that courts produced uniform rulings. For example, if the Court of Cassation made a binding ruling to unify several of its own conflicting judgements (a so-called içtihadı birleştirme kararı), that ruling could be entered into a computer so that all future Court of Cassation rulings that did not adhere to it would be automatically rejected. ${ }^{75}$ Against those who argued that a computer could not exercise discretion, Akman contended that discretion was a matter of evaluating the smallest nuances of an issue, a task for which computers were far better suited than any human, whether an individual judge or the General Assembly of the Court of Cassation with its fifty-eight voting judges. Importantly, he argued, electronic machines have no emotional structure, whereas judges, prosecutors, and attorneys do, making them more susceptible to bias.

\footnotetext{
${ }^{73}$ Hukukta Sibernetik ve Bilgisayar Kullanımı Semineri (Ankara: Milli Prodüktivite Merkezi, 1975), 49-54.

${ }^{74}$ Ibid., $79-86$.

${ }^{75}$ Ibid., 46.
} 
For some of the attendees, the idea that legal interpretation could be carried out by a machine using a logical syntax untainted by the material specificity of individual cases, the semantic openness of natural languages, or the political inclinations of living judges and prosecutors summoned up an ideal judiciary, a legal system with no gaps, ambiguities, or contradictions. As lawyers accustomed to the ideals of the civil law tradition, this vision appeared to bring to their fingertips what H. L. A. Hart described as an unattainable dream: a "mechanical" jurisprudence where "we could make rules, the application of which to particular cases never called for a further choice." ${ }^{76}$ Thus Osman Kuntman of the Ankara Bar Association argued that Akman's ideas might once and for all prevent the accumulation of contradictory precedent-setting appellate rulings. ${ }^{77}$ Similarly, Organ Özdeş, a member of the Council of State, presented his plan for a systematization of rulings from his own court according to the doctrinal concepts or topics they revolved around, a project similar to the one Mustafa Aksoy presented for his workplace, the Court of Cassation. ${ }^{78}$

Although the question of how to encode judicial information as data elicited some interesting discussions, the notion that computers might one day use that data to act as judges met with skepticism. Faruk Erem, a jurist, attorney, and president of the Union of Turkish Bar Associations, emphasized that although computers had infinitely higher cognitive capabilities than human brains, they could never completely supplant them in matters that required administrative or judicial discretion. ${ }^{79}$ A prominent critic of the military trials after the March 1971 coup d'état, Erem may have found it difficult to accept that law could be conceptualized as pure information, abstracted from the materiality of suspenseful courtrooms, the abuse of military prosecutors, and the pain of torture and executions. Implicitly gesturing toward the ongoing violent suppression of political activism, he argued that although computers might be used to ensure a more uniform and equal application of the law, they could not make rulings on their own: "we cannot imagine a death sentence being given by a machine."

It was thus left to the highest official representative of Turkey's beleaguered attorneys to deflate the dream of a cybernetic "judgment machine." Fittingly, the conference in January 1974 came at the tail end of the military regime, after martial law had been lifted but before all of the military trials were completed. Although the conference was a success because of the wide interest it attracted among Turkey's top judicial authorities, the amnesty law that was passed in May that year seemed momentarily to mark the end of both the unrest that had provoked the coup and the violent suppression it had met with. Once political violence picked up pace again in 1977, issues such as reforming the judiciary were soon overshadowed by the sheer anarchy against the backdrop of a persistent financial crisis. The late 1970s brought back again the widespread sense that the integrity of the state itself was at stake. By then, however, cybernetics had outlived its usefulness as a metaphor of judicial and administrative objectivity, leaving behind a state elite unified in its determination to save the state, even at the cost of redefining it as a management apparatus of political demobilization.

\section{Conclusion: The Twilight of the Machines}

With the waning of cybernetics as a metaphor of governance, the ideal of a politically neutral machinery of state also lost some of its credibility. By the time the Turkish Armed Forces carried out a third military coup on 12 September 1980, the above-parties position of the technocrats who came to power after March 1971 had lost its plausibility. Leftists soon discovered, through the purges, arrests, and torture it unleashed on anyone suspected of spreading socialist ideas, that the interim regime veered sharply toward the right. Once martial law was lifted, the veil of objectivity became increasingly transparent to the rest of Turkish society. Ali Elverdi, the chief judge of the court-martial that sentenced Deniz Gezmiş and his two comrades to death in 1972, made the controversial decision to join Süleyman Demirel's Justice Party in 1974. The "impartial" Prime Minister Nihat Erim, formerly a member of the RPP, had himself advised president Cevdet Sunay to ratify the death sentences; a few years later,

\footnotetext{
${ }^{76}$ H. L. A. Hart, The Concept of Law (Oxford, UK: Clarendon Press, 1961), 128.

${ }^{77}$ Hukukta Sibernetik, 62-70.

${ }^{78}$ Ibid., 55-62, 113-28.

${ }^{79}$ Ibid., 131.
} 
he appeared as a guest speaker at the Hearth of Intellectuals (Aydınlar Ocağı), a right-wing association of religious conservative scholars and intellectuals founded in 1970, and cited the ultranationalist Alparslan Türkeş in support of providing executive authorities with wider powers. ${ }^{80}$ The Hearth of Intellectuals, meanwhile, became influential through its "Turkish-Islamic synthesis," the thesis that Turkish identity was built on the twin foundations of Turkish culture and Islam-an idea that the army leadership helped spread after the 1980 coup in the belief that it would inoculate the young against radicalism. ${ }^{81}$

These shifts were also bound to affect the development of cybernetic thinking in Turkey. On the international stage, the 1980s were the decade when the cybernetic ideas of theorists such as Margaret Mead, Gregory Bateson, and Heinz von Foerster found a larger audience, leading some social scientists to abandon the control- and governance-oriented research of Stafford Beer, Talcott Parsons, and Karl Deutsch in favor of "second-order cybernetics," a conception of systemic unity that emphasized reflexivity and complexity rather than integrity and governance. ${ }^{82}$ In Turkey, too, Ali İrtem and Toygar Akman began exploring vistas that took them beyond the realm of government and adjudication. An indication of İrtem's ambitions can be gleaned from his letter to von Foerster in 1982, encouraging him to "simulate the higher capabilities of the human mind and soul, like hypnotism and clairvoyance as well as the other metapsychological events, in cybernetic machines." ${ }^{83}$ Meanwhile, Akman became a very prolific writer on all cybernetic topics, first investigating cybernetic perspectives on art and literature and eventually writing fiction himself. ${ }^{84}$

Among the more conservative of İrtem and Akman's colleagues, however, cybernetics remained a point of reference, functioning now more as an interface between the state and religious conservatives than as a fully fledged technoscientific utopia. Ayhan Songar, the psychiatrist whose 1960 volume on neurology had provided İrtem and Akman with their first platform for writing about cybernetics, became president of the Hearth of Intellectuals in 1979, a position he held until $1984 .{ }^{85}$ With friends such as Nihal Atsız and Necip Fazıl Kısakürek-and later, Recep Tayyip Erdoğan, who visited him on his deathbed-Songar was in a position to convince conservatives that cybernetics was compatible with an Islamic worldview and that it could be put to use to de-radicalize Turkish society. ${ }^{86}$ "Ever since Creation was created," he argued, it "has worked through a variety of feedback connections, and this order has been fine-tuned by the Great Creator within a system that boggles the mind; no one can transgress the boundaries He has drawn." ${ }^{87}$ Nevertheless, he continued, within our systemic parameters, the creator has given living beings a certain amount of free will. Although the future might produce "electronic judges" capable of determining guilt, therefore, Songar did not believe there would ever be entirely "judgeless courts," as there would always be a need for humans to determine the level of punishment. ${ }^{88}$ Indeed, the element of indeterminate discretion also was "why the Turkish Criminal Code recognizes the concept of free consciousness and action and determines punishment in accordance with it"-a topic to which he intended to devote a future book. ${ }^{89}$

\footnotetext{
${ }^{80}$ Nihat Erim, “Anayasa ve Devlet Yönetimi,” in Türkiye’de Hukuk Çıkmazı, ed. Yılmaz Altuğ (Istanbul: Aydınlar Ocă̆ı, 1978), 161-89.

${ }^{81}$ Erik Jan Zürcher, Turkey: A Modern History (London: I. B. Tauris, 2004), 288.

${ }^{82} \mathrm{~A}$ particularly prominent theorist to take up von Foerster's lead was Niklas Luhmann, whose sociological "theory of observing systems" became the primary rival to Jürgen Habermas's theory of communicative action in Germany. See Niklas Luhmann, Soziale Systeme: Grundriss einer allgemeinen Theorie (Frankfurt: Suhrkamp, 1984).

${ }^{83}$ Ali İrtem, "Comment from a Reader," ASC News: Newsletter of the American Society for Cybernetics, no. 14 (1982): 2. See also University of Vienna Heinz von Foerster Archive 10.6.5, letter from İrtem to von Foerster; and Ali İrtem, "Simulation of Free Will," in Current Topics in Cybernetics and Systems: Proceedings of the Fourth International Congress of Cybernetics and Systems, Amsterdam, The Netherlands, August 21-25, 1978 (Berlin: Springer Verlag, 1978), 148-49.

${ }^{84}$ Toygar Akman, Evren Boyutları ve İnsan (Istanbul: Milliyet Yayınları, 1978); Toygar Akman, Dünyanın Sibernetik Oluşumu (Karacan Yayınları, 1982); Toygar Akman, "Sibernetik ve sanat," Sanat Olayı, March 1982; Toygar Akman, "Sibernetik ve Resim Sanatı," Sanat Olayı, May 1982; Toygar Akman, Sibernetik Yaratıcılık (Ankara: Bilgi Yayınevi, 1984); Toygar Akman, Datça Akşamları (Istanbul: Seyran Yayın, 1997); Toygar Akman, Çin'e Yolculuk (Istanbul: Kaknüs Yayınları, 2000).

${ }^{85}$ For more on Songar's post-1980 career, see Zeynep Bursa-Millet, "Traiter le péril jeune: Ayhan Songar, un psychiatre au service du régime militaire en Turquie (1980-1983)," Le Mouvement social, no. 267 (2019): 47-61.

${ }^{86}$ Beşir Ayvazoğlu, “Ayhan Songar," Aksiyon, 12 July 1997; Nihat Gasgar, "Prof. Ayhan Songar Hoca vefat etti,” Zaman, 4 July 1997.

${ }^{87}$ Ayhan Songar, Sibernetik (Istanbul: Yeni Asya Yayınları, 1979), 61.

${ }^{88}$ Ibid., $140-41$.

${ }^{89}$ Ibid., 66.
} 
That book never materialized. Songar did, however, apply his approach to discussing how cybernetic psychiatry could be used to determine the presence or absence of criminal intent and to treat the causes of political violence, which he saw as a primarily psychiatric issue. ${ }^{90}$ After the 1980 coup, he is said to have helped the pharmacological psychiatrist Turan İtil conduct drug tests on political prisoners in the Erzurum military prison. ${ }^{91}$ Meanwhile, Sedat Akalın, the management scholar at Ege University, was elected assistant dean of his university. ${ }^{92}$ Like Songar, Akalın took advantage of the general staffs post-1980 opening toward political Islam by contributing several articles on cybernetics to Sizintı (Fountain), the journal that Fethullah Gülen's Hizmet movement used to demonstrate that the newest scientific discoveries were in keeping with Islam; in the 1991 parliamentary elections he also stood for election as an MP for the Welfare Party (Refah Partisi), Necmettin Erbakan's Islamist party. ${ }^{93}$

Among Turkish judges, prosecutors, and attorneys, however, the ideas of İrtem and Akman were largely forgotten. By the mid-1980s, the more fanciful aspects of cybernetics had largely fallen by the side of the road, leaving only computers-still referred to as the "cybernetic method" (sibernetik metod) - as a promising judicial and administrative technology. ${ }^{94}$ The reason for the loss of interest in cybernetic law was not, I have suggested, that it was unrealistic. Beyond the relatively simple technology involved in storing files, the cybernetic state machines of İrtem and Akman had always had an air of science-fiction about them. Although the notion that basic state functions such as legislating, judging, and punishing might one day be entirely left to computers might have fascinated leaders frustrated by the political fragmentation of their own institutions, it ultimately functioned as a reductio ad absurdum that forced them to confront, and perhaps embrace, their personal complicity in the violent suppression of politically mobilized youth. As attorney Faruk Erem reminded Akman in the 1974 seminar, for better or for worse, there were real humans inside the mechanical Atatürk.

What led Turkish state thinkers to abandon cybernetics was therefore not that they stopped believing in it; it was rather that it had fulfilled its task. Cybernetics had enabled statesmen who were divided by lifestyle, religious beliefs, and views on the state's role in economic life to collectively imagine a space of governing where the struggle between irreconcilable visions of Turkish society would be replaced by a homeostatic balance of freedom and constraint, a vision that happened to be compatible with the corporate solidarism of Kemalism. Viewed through the metaphor of cybernetics, Mustafa Kemal Atatürk's state ceased to be imagined as an organization of individuals and corporate groups united in a common sense of nationhood and progress, and became instead a system of information flows and feedback loops, "a system to be assembled and disassembled rather than an entity whose organic wholeness can be assumed." 95 As a result, a political crisis that was tearing Turkish society apart could be transposed into a conception of cybernetically ordered complexity. In this vision, the only association with the violence that the Turkish state was administering was a faint echo of the friend-enemy distinction on which Norbert Wiener's wartime technology was built, now cleansed of materiality and raised to the level of pure information where it reappeared as a continuous transformation of entropy into systemic stability. ${ }^{96}$ Although cybernetics did not make their divisions disappear, it did function as a convenient fiction that allowed state leaders to put disagreements aside and realign themselves as allies in the fight against political radicalism. Once that realignment was consummated by the 1980 coup, the dream of a technologically unified state was forgotten.

\footnotetext{
${ }^{90}$ Ayhan Songar, "Psikiyatri Açısından Ceza Ehliyeti," Ankara Barosu Dergisi, no. 6 (1976): 1049-59; Ayhan Songar, "Psikolojik Açıdan Toplumda Şiddet,” İstanbul Üniversitesi Hukuk Fakültesi Mecmuası 48, no. 1-4 (1982).

${ }^{91}$ Ertuğrul Mavioğlu, Asılmayıp Beslenenler (Istanbul: İthaki Yayınları, 2006), 225-28. The accusations were brought up in the Grand National Assembly in 1985 (TBMM Tutanak Dergisi, vol. 16, period 17, session 100, 23 July 1985.) See also Bursa-Millet, “Traiter le péril jeune," 56-59.

${ }^{92}$ Hakkı Bilgehan, İsmet Ertaş, and Birol Akşit, Kuruluşundan Günümüze Ege Üniversitesi 1955-2005 (İzmir: Ege Üniversitesi Basımevi, 2005), 702.

${ }^{93}$ Resmi Gazete 21011, 4 October 1991, 97. Akalın's articles appeared in several issues of the 1982 volume of Sizintı.

${ }^{94}$ Ahmet Hamdi Ünlü, “Türk Yargısının Bazı Sorunları," Ankara Barosu Dergisi, no. 1 (1984): 10.

${ }^{95}$ N. Katherine Hayles, How We Became Posthuman: Virtual Bodies in Cybernetics, Literature, and Informatics (Chicago: University of Chicago Press, 1999), 160.

${ }^{96}$ Peter Galison, "The Ontology of the Enemy: Norbert Wiener and the Cybernetic Vision," Critical Inquiry 21, no. 1 (1994): 228-66.
} 
Acknowledgments. This article originates in research carried out in Turkey in 2013-14 and was first presented at MESA in 2017 with the Philip K. Dick-inspired title "Do Torturers Dream of Electric Sheep?" A second version was presented at MESA in 2020. In addition to my fellow panelists and audience members at those two conferences, I would like to thank Ali Açıkgöz, Alp Eren Topal, S. Vedat Karaarslan, Tuncer Ören, the late Albert Müller, Elena Chiti, Stuart Umpleby, Geoffrey Bowker, Jørgen Jensehaugen, and Jacob Høigilt for assisting and providing valuable feedback during various stages of the research for this article. I also would like to thank the article's three anonymous peer reviewers for engaging constructively with my argument: Their comments were immensely helpful. Finally, I want to thank IJMES editor Joel Gordon for enthusiastic support and exacting editing.

Cite this article: Parslow J (2021). The Mechanical Atatürk: Cybernetics and State Violence in the Second Turkish Republic. International Journal of Middle East Studies 53, 569-588. https://doi.org/10.1017/S0020743821001033 